\title{
MECHANISMS OF ADAPTATION TO INTENSIVE LOADS OF 400 METERS' HURDLES RUNNERS AT STAGE OF INITIAL BASIC TRAINING
}

Rovniy A.S., Lastochkin V.M.

Kharkov State Academy of Physical Culture

Sumy State A.S.Makarenko Pedagogical University

\begin{abstract}
Purpose: is study of adaptation mechanisms of 400 meter' hurdles-runners to intensive physical loads. Material: in the research 13 - 400 meters' hurdles-runners and 13 - 400 meters' runners participated. Results: it was found that physiological cost of sportsmen's special workability has fragmentary character. We presented results of physiological and bio-chemical adaptation mechanisms to dozed work. The received results have no confident distinctions and can not objectively characterize mechanisms of sportsmen's special workability. We did not detect definite differences in indicators of mechanisms, ensuring sportsmen's special workability under dozed loads. We found, that level of anaerobic glycolysis is an objective criterion of 400 meter' hurdles-runners' special workability. It was shown that for determination of functional potentials for such kind of functioning it is necessary to apply special loads. Conclusions: the received results deepen information about mechanisms of adaptation to specific competition functioning. Correct approaches to processing and analysis of the research's results permit to more specifically determine sportsmen's functional potentials in different kinds of competition functioning.
\end{abstract}

Key words: adaptation, anaerobic glycolysis, lactate, specific, non-specific, distance.

\section{Introduction}

The problem of adaptation to physical loads is one of the main in system of training in different kinds of sports. Alongside with specific character of adaptation in every kind of sports, there are some general principles and laws [3, 18]. Physical loads' duration and intensity are important factors of sportsmen's adaptation to them as well as individual sensitivity to anaerobic hypoxic impacts [3, 19].

Sport achievements in 400 meters hurdles are not sufficient in Ukraine. That is why registration of adaptation responses in process of sportsmen's training is one of main factors of management of training process $[1,4]$.

Analysis of literature data witnesses that to large extent aspects of sportsmen's organism's adaptation to physical loads in running smooth distances have been studied rather in detail [12, 14, 20]. Comparative characteristic of adaptation responses of 400 meters hurdles-runners under different training loads will facilitate optimization of training process. Just this fact preconditioned the topicality of the given research.

Purpose, tasks of the work, material and methods of the research

The purpose of our work was studying of 400 meter' hurdles-runners' mechanisms of adaptation to intensive physical loads.

\section{The tasks:}

- To determine optimal scopes of training loads for 400 meters' hurdles-runners on the base of physiological and bio-chemical reactions;

- To determine the most adequate combination of load and rest in process of training of 400 meters' hurdles-runners;

Material and methods of the research: in the research 13 - 400 meters' hurdles-runners and $13-400$ meters' runners participated. Sportsmen fulfilled work on treadmill with constant angle of elevation of $3^{\circ}$. The sportsmen endured load with step-by-step increasing of intensity: from 2.5 m.p.sec. to 0.5 m.p.sec. (transition every 2 minutes and further - up to the end). Determination of maximal oxygen consumption (MOC) was carried out by automatic gas analyzer "Backman" with computer data registration. Before and after loads the tested underwent blood sampling from finger for determination of acid-base balance $(\mathrm{pH})$ and concentration of lactate (HL).

(c) Rovniy A.S., Lastochkin V.M., 2015

http://dx.doi.org/10.15561/20755279.2015.0306 


\section{Results of the research}

Analysis of mean group values showed that during work on treadmill ventilation of sportsmen's lungs increases sharply in comparison with rest state (more than 10 times) (see table 1). Increase of lungs' ventilation results from increase of oxygen consumption during work. It is witnessed by coefficient of correlation: between MOC and lung ventilation $(\mathrm{r}=0.65)$; MOC and carbon dioxide $\left(\mathrm{CO}_{2}\right)$ accumulation $(\mathrm{r}=0.54)$.

Table 1

Indicators of maximal physiological and bio-chemical reactions of 400 meters hurdles-runners before and after work on treadmill

\begin{tabular}{|c|c|}
\hline Before load & After load \\
\hline Indicators $(\mathrm{M} \pm \mathrm{m})$ & Indicators $(\mathrm{M} \pm \mathrm{m})$ \\
\hline HBR $62.3 \pm 0.47$ & HBR $198.9 \pm 9.0$ \\
\hline $\mathrm{PCO}_{2}(\mathrm{~mm}) 39.43 \pm 0.58$ & $\mathrm{PCO}_{2}(\mathrm{~mm}) 42.35 \pm 1.37$ \\
\hline $\mathrm{PO}_{2}$ (mm.merc.col) $70.53 \pm 1.98$ & $\mathrm{PO}_{2}$ (mm.merc.col) $80.76 \pm 1.38$ \\
\hline $\mathrm{pH}$ (conv.un.) $7.38 \pm 0.02$ & $\mathrm{pH}$ (conv.un.) $7.12 \pm 0.03$ \\
\hline HL (mol p.l) $2.7 \pm 0.13$ & HL (mol p.l) $11.6 \pm 0.84$ \\
\hline LV (1.p.min.) 12.78 \pm 0.31 & LV (1.p.min) $134.4 \pm 6.87$ \\
\hline
\end{tabular}

Notes: * Work up to the end lasted in average 8-14 min.; * MOC with such work- 68.77 \pm 1.64 ml.p.kg.p.min. $\mathrm{HBR}$ - heart beats rate; LV - lung ventilation; $\mathrm{PCO}_{2}$ - partial pressure of carbon dioxide; $\mathrm{PO}_{2}$ - partial pressure of oxygen; $\mathrm{pH}$ - homeostasis (acid-base balance); HL - lactate.

We determined the state of homeostasis and differences in it as well as differences in character of HL removal from blood in rest period. In some sportsmen lactate quickly diffused from muscles to blood and was quickly removed from blood. But there were cases when lactated diffused only by $10^{\text {th }}$ minute of rest.

Quantity of lactate in blood by $20^{\text {th }}$ minute of rest is confidently connected with maximal $\mathrm{pH}$ level $(\mathrm{r}=0.540)$, reserves of buffer bases $(\mathrm{r}=0.580)$, value of oxygen $\mathrm{O}_{2}$ supply $(\mathrm{r}=0.590)$.

Having determined general regularities of physiological and bio-chemical parameters' dynamic under load on treadmill we made attempt to compare adaptation reserves of 400 meters' runners and 400 meters' hurdles-runners (see table 2).

Table 2

Comparative characteristic of physiological and biochemical indicators, taken in process of work on treadmill, of 400 meters runners and 400 meters' hurdles-runners.

\begin{tabular}{|c|c|c|c|c|c|c|c|c|c|c|c|c|}
\hline \multicolumn{6}{|c|}{ In rest } & \multicolumn{7}{|c|}{ After load } \\
\hline HBR & LV & HL & $\mathrm{pH}$ & $\mathrm{PCO}_{2}$ & $\mathrm{PO}_{2}$ & HBR & LV & MOC & $\mathrm{pH}$ & HL & $\mathrm{PCO}_{2}$ & $\mathrm{PO}_{2}$ \\
\hline \multicolumn{13}{|c|}{400 meters' hurdles-runners } \\
\hline 61.0 & 12.5 & 1.44 & 7.37 & 39.7 & 69.8 & 187.8 & 140.7 & 69.2 & 7.11 & 13.36 & 42.24 & 73.7 \\
\hline \multicolumn{13}{|c|}{400 meters' runners } \\
\hline 62.4 & 11.56 & 1.74 & 7.39 & 39.8 & 69.8 & 205.4 & 132.4 & 67.8 & 7.13 & 13.14 & 46.22 & 84.54 \\
\hline
\end{tabular}


Analysis of results witnesses that differences between indicators of functional reactions and physical workability of both groups' sportsmen in laboratory conditions are statistically unconfident ( $p>005)$. We found that duration of work on treadmill is confidently connected with oxidation process of re-synthesis of adenosine triphosphate (ATP): with MOC r $=0.580$. It is known that in 400 meters' run and 400 meters hurdles high role is played by anaerobic glycolysis. Lactate concentration can change from 18 to $27-30 \mathrm{mmol}$ p.l. Therefore functional distinction and functional reserves can not be open to full extent in laboratory conditions (work on treadmill of 400 meters' runners and 400 meters' hurdles-runners).

That is why we made an attempt to compare assessment of sportsmen's competition functioning in specific and non-specific conditions. Wee studied functional condition of 7 the strongest 400 meters' hurdlesrunners. During one day the sportsmen fulfilled two competition loads: in the morning they ran 400 meters' distance as hurdles-runners; after 3 hours they ran 400 meters' smooth distance. The competitions were of selective character.

These competitions were conducted against the background of ordinary training process (there were no fasting days before competitions). That is why in blood we observed significant values of lactate ( $2.97 \pm 0.14$ and $3.13 \pm 0.24 \mathrm{mmol}$ p.l.). This fact points at finishing of recreational process.

Mean indicator of time of 400 meters' hurdles was $52.39 \pm 0.46$; of 400 meters of smooth run $49.83 \pm 0.38 \mathrm{sec}$. (differences are confident $\mathrm{p}<0.01$ ).

Analysis of HBR response to specific and non-specific loads did not show statistically confident differences $(\mathrm{p}>0.05)$ (see table 3$)$.

Table 3

Influence of specific and non-specific competition loads on functional and bio-chemical indicators of 400 meters' hurdles-runners

\begin{tabular}{|l|l|l|l|l|}
\hline \multirow{2}{*}{\multicolumn{1}{|c|}{ Indicators }} & \multicolumn{2}{c|}{400 meters' hurdles } & \multicolumn{2}{c|}{400 meters' run } \\
\cline { 2 - 5 } & \multicolumn{1}{|c|}{ In rest } & After load & In rest & After load \\
\hline HBR & $84.0 \pm 1.20$ & $197.0 \pm 9.1$ & $71.0 \pm 0.41$ & $184.0 \pm 3.1$ \\
\hline Lactate (mmol p.l.) & $2.77 \pm 0.31$ & $16.93 \pm 1.36$ & $3.13 \pm 0.49$ & $19.39 \pm 0.78$ \\
\hline Glucose (mmol p.l.) & $7.09 \pm 0.74$ & $5.77 \pm 0.33$ & $4.57 \pm 0.48$ & $6.37 \pm 0.71$ \\
\hline
\end{tabular}

Confident distinctions were observed when combining bio-chemical reactions to certain load. Different speed of run influenced differently on intensity of anaerobic glycolysis. Its indicator was level of lactate after work. As we can see this indicator is confidently higher with 400 meter" "smooth" run.

Increase of glucose in blood under less loads witnesses about mobilization of carbohydrate reserves of liver [4]. With fulfillment of two competition loads we observed glucose concentration in both cases. But its dynamic (rest-work-recreation) is ambiguous (see table 3).

Analysis of metabolic responses with fulfillment of two competition loads showed that sportsmen with high result on both distances did not differ significantly by functional responses. On the base of results of the research we can assume that the most promising for 400 meters' hurdles are sportsmen with high level of anaerobic glycolysis in "smooth" 400 meters' run.

\section{Discussion}

In process of training and competition functioning there appear changes of functional systems, which significantly increase special workability. Presence of objective information about levels of sportsmen's fitness permits to determine strong and weak sides of sportsmen's fitness. As a result it is possible to optimize training process $[3,4,9,10,11]$.

In kinds of sports with complex coordination against the background of speed-power endurance combination of anaerobic abilities with motor coordination is of great importance. Especially it is important in hurdles. Analysis of literature data witnesses that most of researches are devoted to different problems of sportsmen's training in "smooth" run. These researches dealt with development of hypoxic potentials $[6,11,13]$. 
The existing researches (A.L. Novikova, I.N. Soroka, 1994) recommend significant increasing of physical fitness [5]. S.V. Biriuk (2001) pays special attention to formation of run rhythm in hurdles on initial stage [1]. Chi Dunlin recommends to pay special attention to speed-power and coordination training [9, 10].

However, fundamental researches [2, 5, 15, 16, 17] show that in kinds of sports of sub maximal intensity study of oxygen demand and work's fulfillment energy cost as well as organism's adaptation potentials are of great importance.

However, with usage of dozed loads it is impossible to exactly restore advantages of sportsmen of different run specializations (L.G. Kharitonova, 1991; A.S. Rovniy, V.A. Rovniy 2009) [7, 8]. It is confirmed in our researches. We also affirm that for determination of functional potentials for certain kind of activity it is necessary to apply special loads.

Thus, the received results deepen information about specific features of mechanisms of adaptation to specific competition functioning. Correct approaches to processing and analysis of results of the research permit to more specifically determine sportsmen's functional potentials in different kinds of competition functioning.

\section{Conclusions}

Determination of promising sportsmen in laboratory conditions does not reflect actual special workability. Level of anaerobic glycolysis is a limiting factor of special workability of 400 meters' hurdlesrunners. The received results permit to say that application of the mentioned in this paper methods of research give objective information about special workability indicators and makes possible to prognosticate level of sport achievements.

\section{Conflict of interests}

The authors declare that there is no conflict of interests.

Reference

1. Biriuk SV. Formuvannia ritmu bigu z bar'ierami u khlopciv 13-15 rokiv na pochatku sportivnoi specializacii. Cand. Diss. [Formation of 13-15 years old boys' run rhythm in hurdles at the beginning of sport specialization. Cand. Diss.], Mikolaiv; 2001. (in Ukrainian)

2. Volkov NI, Biriuk SV, Savel'ev IA. Kislorodnyj zapros i energicheskaia stoimost' napriazhennoj myshechnoj deiatel'nosti [Oxygen demand and energy cost of tensed muscular functioning]. Fiziologiia cheloveka, 2002;28(4): 80-93. (in Russian)

3. Krivoshchekov SG, Divert GM, Divert VE. Rasshirenie funkcional'nogo diapazona reakcij dykhaniia i gazoobmena pri povtornykh gipoksicheskikh vozdejstviiakh [Expanding of functional range of gas metabolism and respiratory responses under repeated hypoxic impacts]. Fiziologiia cheloveka, 2005;31(3):100-107. (in Russian)

4. Mishchenko VS, Lysenko EN, Vinogradov VE. Reaktivnye svojstva kardiorespiratornoj sistemy kak otrazhenie adaptacii $k$ napriazhennoj fizicheskoj trenirovke $v$ sporte [Responsive characteristics of cardiorespiratory system as reflection of adaptation to intensive physical training in sports]. Kiev; 2007. (in Russian)

5. Novikov AL, Soroka IN. Trenirovka v bege na $400 \mathrm{~m} \mathrm{~s}$ bar'erami (muzhchiny) [Training in 400 meters hurdles (male)], Minsk; 1994. (in Russian)

6. Rovnaia OA, Il'in VN. Osobennosti adaptivnykh reakcij sistemy dykhaniia vysokvalificirovannykh sportsmenok sinkhronnogo plavaniia vo vremia interval'noj gipoksicheskoj trenirovki [Specific features of respiratory system's adaptation responses of elite synchronous swimmers during interval hypoxic training]. Pedagogics, psychology, medical-biological problems of physical training and sports, 2010;1:71-75. (in Ukrainian)

7. Rovnij AS, Rovnyj VA. Upravlenie sistemoj podgotovki iunykh begunov na $400 \mathrm{~m} \mathrm{~s}$ bar'erami [Management of junior 400 meters' hurdles-runners' training]. Slobozhans'kij naukovo-sportivnij visnik, 2009;1:72-75. (in Russian)

8. Kharitonova LG. Fiziologicheskie i biokhimicheskie aspekty adaptacii k intensivnym nagruzkam organizma begunov na $400 \mathrm{~m}$ s bar'erami [Physiological and bio-chemical aspects of adaptation to organism's intensive loads of 400 meters' hurdles-runners]. Teoriia i praktika fizicheskoj kul'tury, 1991;1:9-12. (in Russian) 
9. Shi Dulin. Skorostno-silovaia podgotovka iunykh begunov na $400 \mathrm{~m} \mathrm{~s}$ bar'erami [Speed-power training of junior 400 meters' hurdles-runners]. Slobozhans'kij naukovo-sportivnij visnik, 2004. 1: 40-43. (in Russian)

10. Shi Dulin. Razvitie koordinacionnykh sposobnostej kak osnova sovershenstvovaniia tekhniki bega na $400 \mathrm{~m}$ $\mathrm{s}$ bar'erami [raining of coordination as the basis of perfection of 400 meters' hurdles technique]. Slobozhans'kij naukovo-sportivnij visnik, 2005;1:125-129. (in Russian)

11. Bailey DM, Davies B, Baker J. Training in hypoxia: modulation of metabolic and cardiovascular risk factors in man. Med.Sci.Sports Exerc, 2000;32(6):1058-1063.

12. Bennet S. Training for $400 \mathrm{~m}$. Human Kinetics Pub; 1999.

13. Chick TW, Stark DM, Murata GH. Hyperoxic training increases work capacity after maximal training at moderate altitude. Chest; 1993;104:1759-1762.

14. Cheng Ping, Wang gig Yu. Technical training of $400 \mathrm{~m}$ Hurdle Race and the Rhythm among Hurdleg. Journal of Shandong Sports Science \& Technology. 2002;3:12-14.

15. Hochachka PW, Rupert JI, Monge C. Adaptation and conservation of physiological system in the evolution of human hypoxia tolerance. Comp. Biochem. Physiol; 1999;124:1-8.

16. Levine BD. Intermittent hypoxic training: fact and fancy. High Alt. Med. Biol., 2002;3(2):177-182.

17. Pearse WJ. Mechanisms of hypoxic cerebral vasodilatation. Pharmac. Tner., 1995;65:75-78.

18. Tian zhong Yan. A research on the contest Rhythm of World mans $400 \mathrm{~m}$ Hurdles. Journal of Shandong institute of Physical Education, 2003;2:103-105.

19. Yang Hui. Analysis on Chinese Excellent Athlete Luli Xiana Score of $110 \mathrm{~m}$ Men Hurdle. Journal of Beijing Sport University, 2003;11:1579-1581.

20. Zhao Jia Gni. On the Training of teen-agers 400-meters Hurdle Race. Journal of Anhui Polytechnic University Social Science, 2001;1:143-144.

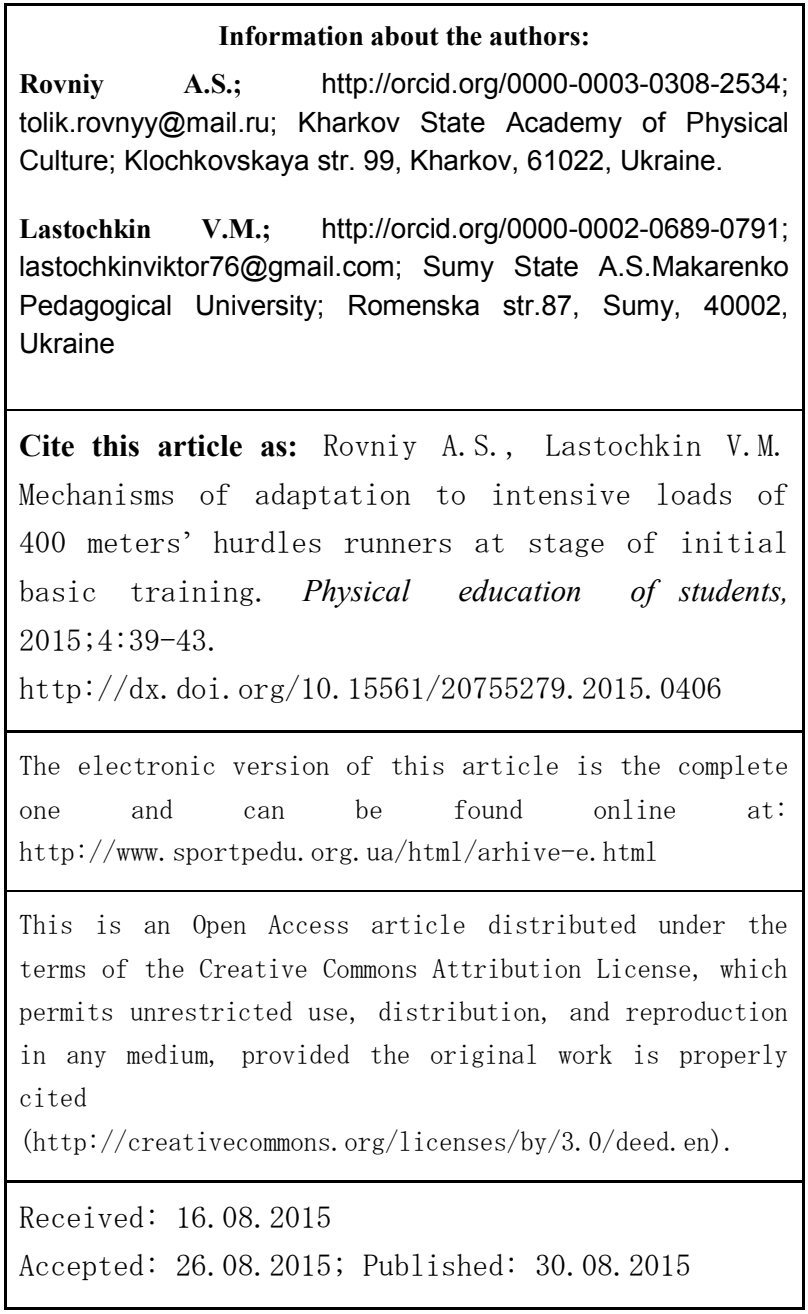


